\title{
Parents' Feeding Style on the Adequacy of Energy and Protein in Children with Stunted Nutritional Status
}

\author{
Puji Afiatna ${ }^{1^{*}}$, Sugeng Maryanto ${ }^{2}$ \\ 1,2 Department of Nutrition Universitas Ngudi Waluyo, Semarang, Indonesia
}

\begin{abstract}
Stunting in children occurs within a certain time; its incidence is closely related to the quantity and quality of food intake, especially the adequacy of energy and protein. Parents with various models of feeding style influence the fulfilment of food intake in children. This study was conducted to analyze the correlation of feeding style with adequate energy and protein levels in stunted children aged 6-9 years. The design in this study was cross-sectional in 91 stunted children aged 6-9 years at West Ungaran, Semarang, who was selected by consecutive sampling. The data was collected using anthropometric measurements and parental feeding style, and the data were analyzed using the Spearman rank test. Parents feeding style was authoritative $(37.2 \%)$, authoritarian $(13.2 \%)$, permissive $(20.9 \%)$, and neglect $(28.6 \%)$. The highest energy adequacy level in children was found in parents with neglect feeding style in the deficit category $(73.1 \%)$. Children's highest protein adequacy level was found in parents with authoritative feeding styles, in the over the category $(50.0 \%)$. Parental feeding style correlated with the adequacy of energy and protein levels in children and impacted the incidence of stunting in children aged 6-9 years.
\end{abstract}

\section{Introduction}

School children are included in a group that is vulnerable to the problem of malnutrition and related with mothers' education and fathers' occupation [1]. One of the malnutrition problems experienced by school children today is stunting (short). This prevalence shows that one-third of children aged 5-12 years in Indonesia are stunted. Based on the WHO, stunting is a public health problem that is considered severe because it is in the range of 3039 per cent [2].

The achievement of the height of a new child entering school is an indicator of the presence or absence of growth disorders in children [3]. Malnutrition in childhood can cause severe disturbances in growth and development, which manifests in physical, mental and intellectual forms, which result in the low quality of human resources [4]. To get quality human resources in the future, children need to be prepared to grow and develop as optimally

\footnotetext{
* Corresponding author: puji.afiatna0912@gmail.com
} 
as possible according to their abilities $[5,6]$. One of them is the practice of providing healthy and nutritious food.

Feeding style is related to the practice of feeding and stimulation gave to children. Poor feeding practices in children will contribute to the incidence of stunting [7]. Parenting patterns are based on parental beliefs about why a child behaves well or misbehaves, including eating behaviour [8].

Parenting pattern consists of two essential elements: parental demandingness, parental (demands), and parental responsiveness (response of parents). Elements of demands in a parenting pattern for children can be realized by providing control, supervision, consistent direction, clear expectations and punishments. In this element, the child brings the child to the dimension of compliance with a set of standards set by parents. In contrast, the response elements in parenting patterns can be seen from parents' warmth, acceptance and involvement of parents in children's daily activities [9].

Parents, especially mothers, play a significant role in the success of shaping children's eating behaviour. A good feeding style will affect children's nutritional intake [10]. Based on this background, researchers are interested in researching the correlation between feeding style and energy and protein adequacy in elementary school children with nutritional status stunting.

\section{Methods}

This study is an observational study using a cross-sectional approach. The research was conducted in 2018 at an elementary school in West Ungaran District, Semarang Regency, Central Java Province. A total of 32 elementary schools were involved in this study. The sampling technique used was the consecutive sampling method.

The data feeding style is taken using the Caregiver's Feeding Style Questionnaire (CFSQ), consisting of 2 parts, namely the demands element consisting of 17 statements and the response element consisting of 5 statements. The scoring ranges from "never" with a score of 1 point to always with 5 points. The scores for each element are then added up. The feeding style is authoritative if the demand element scores the median score and the response element score the median score. Authoritarian feeding style is when the demand element score $\geq$ median score and response element score $\leq$ median score. Feeding style is permissive if the demand element score is $\leq$ the median score and the response element score is $\geq$ the median. Feeding style ignores when demand element score $\leq$ median score and response element score $\leq$ median score [11].

Measurement of the level of energy and protein adequacy by conducting a $3 \times 24$ hour recall interview. Interviews were conducted on subjects with parents. The level of nutritional adequacy of subjects is based on individual needs, which has been adjusted to the 2013 Nutritional Adequacy Rate (AKG). Energy adequacy is deficit if $89 \%$ AKG, energy adequacy is adequate if $90 \%-120 \% \mathrm{AKG}$, and more if $>120 \% \mathrm{AKG}$. Protein adequacy deficit $\leq 89 \%$ $\mathrm{AKG}$, protein adequacy is adequate if $90 \%-120 \% \mathrm{AKG}$, and protein adequacy is more if $>$ $120 \%$ AKG.

Parents, especially mothers, play a significant role in the success of shaping children's eating behaviour. A good feeding style will affect the nutritional intake of children [10]. Based on this background, researchers are interested in researching the correlation between feeding style and energy and protein adequacy in elementary school children with stunting nutritional status. 


\section{Result and discussion}

\subsection{Characteristics of respondents}

A total of 91 children aged 6-9 years were the subjects in this study. The characteristics of the subjects can be seen in Table 1.

Table 1. General characteristics of research subjects.

\begin{tabular}{|c|c|c|c|c|}
\hline Characteristics & $\mathbf{n}$ & $\%$ & $\begin{array}{c}\text { Mean } \\
(\text { SE) }\end{array}$ & Min-Max \\
\hline Age subjects & & & $7.20(0.56)$ & $6.00-8.00$ \\
\hline $6-7$ years old & 66 & 72.5 & & \\
\hline $8-9$ years old & 25 & 27.5 & & \\
\hline \multicolumn{5}{|l|}{ Gender } \\
\hline Female & 47 & 51.6 & & \\
\hline Male & 44 & 48.4 & & \\
\hline $\begin{array}{l}\text { Nutritional status } \\
\text { (Heigh for age) }\end{array}$ & & & $-2.46(0.42)$ & $\begin{array}{c}(-4.43)- \\
(-2.01) \\
\end{array}$ \\
\hline Moderate stunting & 84 & 92.3 & & \\
\hline Severe stunting & 7 & 7.7 & & \\
\hline
\end{tabular}

Based on Table 1, it can be seen that most of the research subjects were aged 6-7 years $(72.5 \%)$ with an equal proportion of sex between men and women. Most of the subjects had short height (92.3\%). Socio-economic characteristics can be seen in Table 2.

Table 2. Socio-economic characteristics of subjects.

\begin{tabular}{|l|c|c|}
\hline \multicolumn{1}{|c|}{ Characteristics } & n & \% \\
\hline Respondents & & \\
\hline Mother & 69 & 75.8 \\
\hline Father & 22 & 24.2 \\
\hline Maternal age & & 23.1 \\
\hline $19-29$ years & 67 & 73.6 \\
\hline $30-49$ years & 3 & 3.3 \\
\hline $50-64$ years & & \\
\hline Father's age & 9 & 9.9 \\
\hline $19-29$ years & 76 & 83.5 \\
\hline $30-49$ years & 6 & 6.6 \\
\hline $50-64$ years & & \\
\hline $\begin{array}{l}\text { Number of dependent } \\
\text { family members }\end{array}$ & 51 & 56.0 \\
\hline $2-4$ people & 40 & 44.0 \\
\hline$>4$ people & & \\
\hline
\end{tabular}

Based on Table 2, it can be seen that the subjects whose overall stunting background were mostly mothers and fathers aged 30-49 years were $73.6 \%$ and $83.5 \%$, respectively. the average age of the mother is 34.32 years with the youngest age 24 years and the oldest 55 
years. The average age of the father is 37.79 with the youngest being 24 years old and the oldest 58 years old.

\section{Daily Child Care}

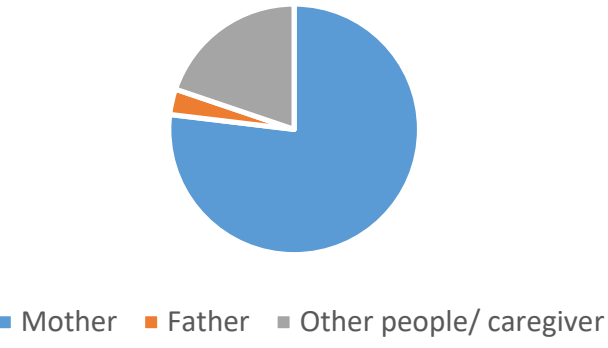

Fig. 1. Daily child care.

Based on Figure 1, it can be seen that some of the subjects were cared for by mothers (76.9\%), while some children were cared for by other people (19.8\%) who were usually grandmothers. Subjects raised by other people generally both parents work outside the home as factory workers.

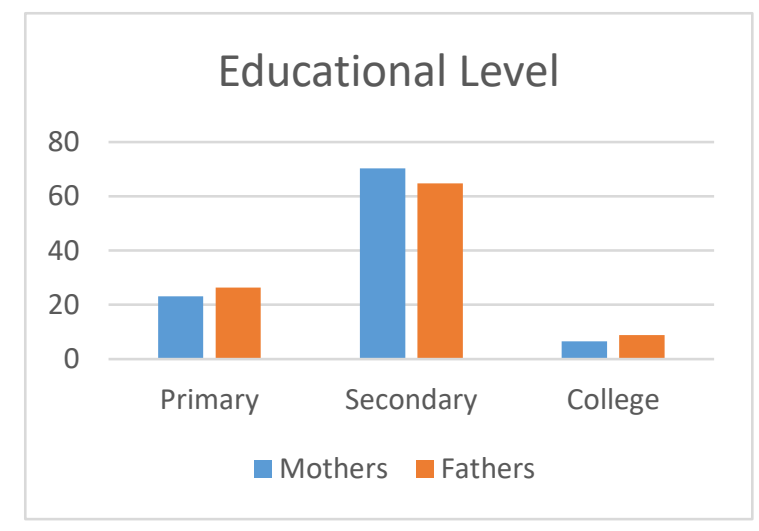

Fig. 2. Educational level of parents. 


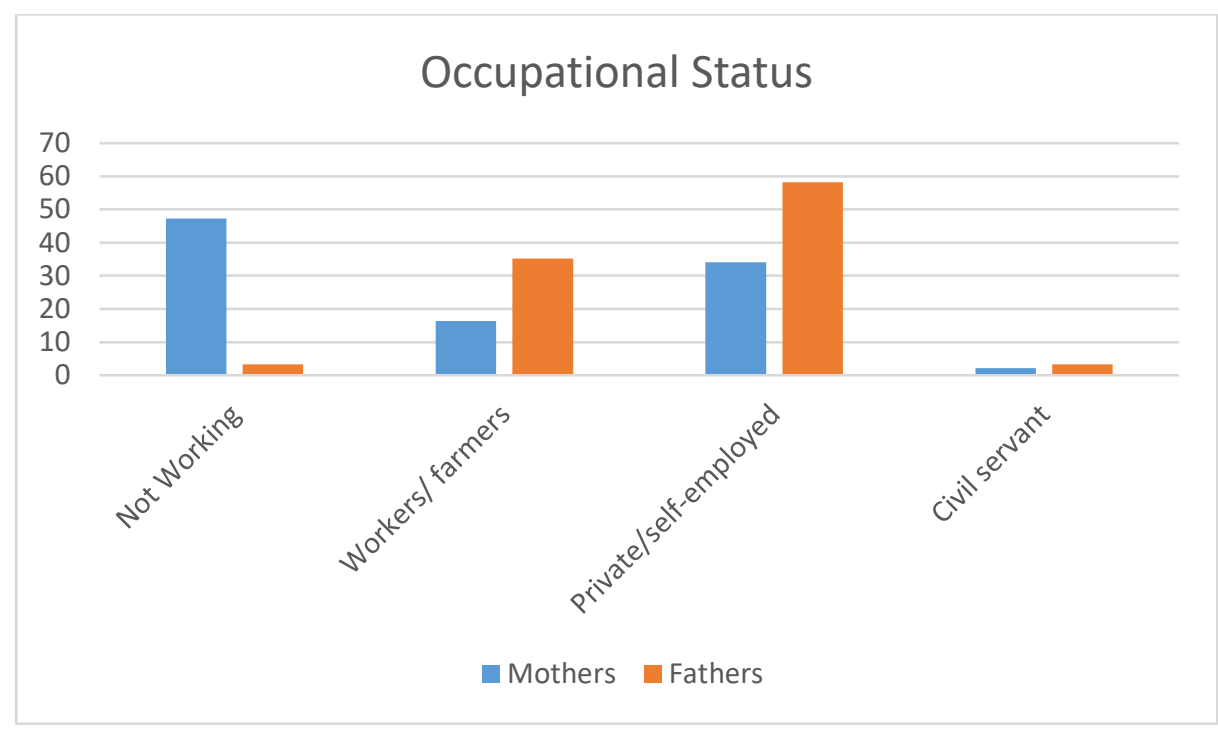

Fig. 3. Occupational status of parents.

Based on Figures 2 and 3, it can be seen that more than half of the subjects had mothers and fathers with secondary level education, namely $70.3 \%$ and $64.8 \%$, although there were still parents who did not complete primary school. Half of the subject's mothers work $(52.7 \%)$, mainly as factory employees and self-employed. Most of the father's work (96.7\%) mainly in the private sector. There are also subjects whose fathers do not work because their mothers work as female workers abroad, so it is the father who takes care of the children.

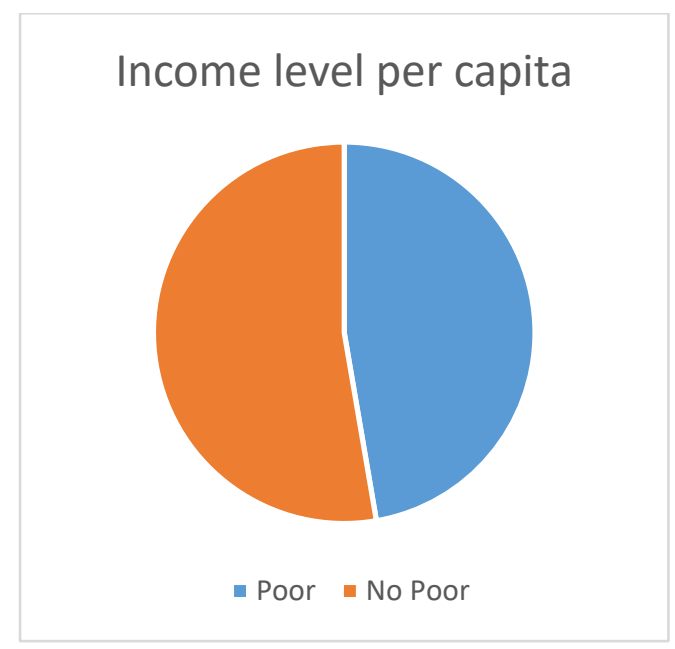

Fig. 4. Income level per capita of subjects.

Based on Figure 4, the number of family members, more than half have 2-4 family members $(56 \%)$. More than half of the subjects with per capita income are included in the non-poor category (52.7\%). This is based on the 2018 BPS poverty line limit, which is Rp. 401,220.00. the average income per capita is $\mathrm{Rp}$. 514.169,00 with the lowest per capita income Rp. 76,923.00, and the highest is Rp. 1,625,000.00. 


\subsection{Adequate level of energy and protein intake}

Adequate levels of energy and protein intake can be seen in Table 3.

Table 3. Adequacy of energy and protein intake of research subjects.

\begin{tabular}{|l|l|l|l|l|}
\hline \multicolumn{1}{|c|}{ Nutrient } & \multicolumn{1}{c|}{ n } & \multicolumn{1}{c|}{ Mean (SD) } & Min- Max \\
\hline $\begin{array}{l}\text { Energy } \\
\text { adequacy level }\end{array}$ & & & $85.44(30.32)$ & $34-163$ \\
\hline Deficit intake & 54 & 69.3 & & \\
\hline Adequate intake & 24 & 26.4 & & \\
\hline More intake & 13 & 14.3 & & $47-211$ \\
\hline $\begin{array}{l}\text { Protein } \\
\text { adequacy level }\end{array}$ & & & & \\
\hline Deficit intake & 29 & 31.9 & & \\
\hline Adequate intake & 26 & 28.6 & & \\
\hline More intake & 36 & 39.5 & & \\
\hline
\end{tabular}

Based on Table 3, it is known that half of the subjects have sufficient energy at the deficit level (69.3\%). Meanwhile, the level of protein adequacy varies, but most subjects have a protein adequacy level in the more category, which is $39.5 \%$.

\subsection{Feeding style practiced by parents}

The scores for the demand and response elements of the feeding style practiced by the subject's parents can be seen in Table 4 .

Table 4. Score of feeding style elements.

\begin{tabular}{|l|l|l|l|}
\hline Element of Feeding Style & Mean (SD) & Median & Min- Max \\
\hline Demandingness element & $55.37(10.48)$ & 56 & $26-76$ \\
\hline Response element & $18.12(3.46)$ & 18 & $7-25$ \\
\hline
\end{tabular}

The feeding style is divided into four types, namely authoritative, permissive, authoritarian, and ignorant. This categorization is based on the median value of each aspect of demand and response [11]. The median score for each aspect of feeding style in this study was 56 for the demand aspect and 18 for the response aspect. Feeding style is authoritative if the score of the demand dimension is $\geq 56$ and the score of the response dimension is $\geq 18$. The feeding style is authoritarian if the score is if the score of the demands dimension $<56$ and the response dimension $<18$.

Table 5. Characteristics of the type of feeding style practiced by the parents of the research subjects.

\begin{tabular}{|l|c|c|}
\hline \multicolumn{1}{|c|}{ Feeding Style } & n & \% \\
\hline Authoritative & 34 & 37.3 \\
\hline Authoritarian & 12 & 13.2 \\
\hline Permissive & 19 & 20.9 \\
\hline Neglect & 26 & 28.6 \\
\hline Total & 91 & 100.0 \\
\hline
\end{tabular}


Based on Table 5, the types of feeding styles that parents practise vary. Most parents practise an authoritative feeding style $(37.3 \%)$, while the rest practice neglect, permissive and authoritarian parenting, respectively $28.6 \% ; 20.9 \%$ and $13.2 \%$.

Each type of feeding style includes two elements, demand and response. High demands followed by high responses also characterize the authoritative eating style of parenting. High demands with low responses indicate an authoritarian feeding style. Permissive feeding style is shown by low demands on children but high responses. Meanwhile, the neglected feeding style is characterized by its low in both dimensions, both demand and response [12].

Parenting is a method for shaping children's character and educating them to practice selfcontrol and behaviour acceptable to society [9]. An effective parenting pattern is being a parent through parenting, discipline and setting an example/life example. Parenting techniques will emerge and develop in everyday family life. A thorough understanding of child development principles can help parents carry out parenting for their children [13].

Each parent is an individual with a past, present, and future development. This makes the application of skills in parenting not different. There are many styles of parenting because the experiences that parents get are also different. Effective parenting has several components, namely caring, playing as good role models and discipline, and communicating feelings, directions and goals to children. Parenting includes many interesting skill dimensions from developing needs, biological impulses, cognition and emotions, psychological intuition, acquired knowledge and competencies, all of which operate in a sociohistorical context [8].

Based on research conducted in Mojokerto on elementary school students, it was found that there was a relationship between feeding style and nutritional status. The style of parenting to eat a good meal will affect the child's diet. A good diet can affect a child's intake. Parents have an essential role in shaping the child's diet. The correct feeding style can be realized by giving loving attention to the child's diet [10].

Traditional patterns are the most effective parenting methods in producing good children's behaviour, including eating behaviour. This parenting pattern has two components, namely responsiveness and high demands. Responsiveness includes warmth, acceptance and involvement of parents in children's daily activities. According to the child's age, behavioural control, close supervision, clear expectations, and consistent direction characterize this parenting style [13].

The authoritarian pattern is a parenting pattern that emphasizes control and obedience that should not be questioned or negotiated by the child. Parents try to apply a set of standards that have been made and punish children if children violate them. Parent relationships tend to be distant from children and less warm. This pattern makes children withdraw, lack confidence and have difficulty communicating with parents [9].

Permissive parenting is a parenting pattern with a high response from parents, but parents have low expectations for their children. The use of permissive parenting is usually variable and unpredictable. It has no clear boundaries and directions [13]. Permissive parenting involves parents making few requests and allowing children to monitor their activities. Parents tend to be less controlling and less demanding of their children [9].

Patterns of neglect or neglect. This parenting pattern describes parents who prioritize their own needs over the needs of their children. This can be because parents experience stress or depression, so it is difficult to divide attention between themselves and their children. This feeding style will result in the emergence of various behavioural disorders in children and adolescents. Thus, this kind of parenting should be avoided $[9,13]$. 


\subsection{The Practice of Feeding Style with nutrient adequacy level}

The practice of feeding style with the subject's nutritional adequacy level. The distribution of the frequency of feeding styles practiced by parents with energy adequacy levels can be seen in Table 6.

Table 6. Frequency distribution of feeding styles with the subject's energy adequacy level.

\begin{tabular}{|c|c|c|c|c|c|c|c|c|c|c|}
\hline \multirow{3}{*}{ Variable } & \multicolumn{6}{|c|}{ Energy Adequacy Level } & & & \multirow{3}{*}{$\mathbf{r}$} & \multirow{3}{*}{$p$} \\
\hline & \multicolumn{2}{|c|}{$\begin{array}{c}\text { Deficit } \\
\text { intake } \\
(n=54) \\
\end{array}$} & \multicolumn{2}{|c|}{$\begin{array}{c}\text { Adequate } \\
\text { intake } \\
(\mathbf{n}=\mathbf{2 4})\end{array}$} & \multicolumn{2}{|c|}{$\begin{array}{l}\text { More intake } \\
\quad(\mathrm{n}=13)\end{array}$} & \multicolumn{2}{|c|}{ Total } & & \\
\hline & $\mathbf{n}$ & $\%$ & $\mathrm{n}$ & $\%$ & $\mathbf{N}$ & $\%$ & $\mathrm{n}$ & $\%$ & & \\
\hline $\begin{array}{l}\text { Feeding } \\
\text { Style }\end{array}$ & & & & & & & & & -0.199 & 0.058 \\
\hline $\begin{array}{l}\text { Authoritati } \\
\text { ve }\end{array}$ & 34 & 37.3 & 11 & 32.4 & 7 & 20.6 & 34 & 100.0 & & \\
\hline $\begin{array}{l}\text { Authoritari } \\
\text { an }\end{array}$ & 12 & 13.2 & 3 & 25.0 & 1 & 8.3 & 12 & 100.0 & & \\
\hline Permissive & 19 & 20.9 & 6 & 31.6 & 2 & 10.5 & 19 & 100.0 & & \\
\hline Neglect & 26 & 28.6 & 4 & 15.4 & 3 & 11.5 & 26 & 100.0 & & \\
\hline
\end{tabular}

Based on Table 6, it can be seen that parents who practice negligent feeding style have a proportion of children with a greater energy deficit level (73.1\%) compared to authoritarian (66.7\%), permissive $(57.9 \%)$ and authoritative (47.1\%). Based on the Spearman Rank bivariate test, it shows that feeding style is not related to the level of energy adequacy as indicated by a p-value of $0.058(\mathrm{p}>0.05)$, with the strength of the correlation included in the fragile category $(\mathrm{r}=0.199)$.

The distribution of the frequency of feeding styles practised by parents with protein adequacy levels can be seen in Table 7 .

Table 7. Frequency distribution of feeding styles with the subject's protein adequacy level.

\begin{tabular}{|c|c|c|c|c|c|c|c|c|c|c|}
\hline \multirow{3}{*}{$\begin{array}{l}\text { Variabl } \\
\text { e }\end{array}$} & \multicolumn{6}{|c|}{ Protein Adequacy Level } & & & \multirow{3}{*}{$\mathbf{r}$} & \multirow{3}{*}{$p$} \\
\hline & \multicolumn{2}{|c|}{$\begin{array}{c}\text { Deficit } \\
\text { intake } \\
(\mathrm{n}=29)\end{array}$} & \multicolumn{2}{|c|}{$\begin{array}{c}\text { Adequate } \\
\text { intake } \\
(\mathbf{n}=\mathbf{2 5})\end{array}$} & \multicolumn{2}{|c|}{$\begin{array}{l}\text { More intake } \\
\quad(\mathbf{n}=\mathbf{3 7})\end{array}$} & \multicolumn{2}{|c|}{ Total } & & \\
\hline & $\mathrm{n}$ & $\%$ & $\mathrm{n}$ & $\%$ & n & $\%$ & $\mathbf{n}$ & $\%$ & & \\
\hline $\begin{array}{l}\text { Feeding } \\
\text { Style }\end{array}$ & & & & & & & & & -0.157 & 0.138 \\
\hline $\begin{array}{l}\text { Authoritat } \\
\text { ive }\end{array}$ & 8 & 23.5 & 9 & 26.5 & 17 & 50.0 & 34 & 100.0 & & \\
\hline $\begin{array}{l}\text { Authoritar } \\
\text { ian }\end{array}$ & 4 & 33.3 & 4 & 33.3 & 4 & 33.3 & 12 & 100.0 & & \\
\hline $\begin{array}{l}\text { Permissiv } \\
\mathrm{e}\end{array}$ & 8 & 42.1 & 4 & 22.1 & 7 & 36.8 & 19 & 100.0 & & \\
\hline Neglect & 9 & 34.6 & 8 & 30.8 & 9 & 34.6 & 26 & 100.0 & & \\
\hline
\end{tabular}


Based on Table 7, it can be seen that parents who practice permissive style feeding have a more significant proportion of children with a protein deficit adequacy level $(42.1 \%)$ than permissive (34.6\%), authoritarian (33.3\%) and authoritative $(23,5 \%)$. Parents who practice an authoritarian feeding style have a higher proportion of children with good protein adequacy $(33.3 \%)$ than those who are ignorant $(30.8 \%)$, authoritative $(26.5 \%)$ and permissive $(21.1 \%)$. Based on the Rank Spearman bivariate test, it showed that feeding style was not related to the level of protein adequacy as indicated by a p-value of $0.138(p>0.05)$, with the strength of the correlation included in the fragile category $(\mathrm{r}=-0.157)$.

Complete and adequate nutritional intake can be obtained from a variety of foods. Based on research conducted in East Java regarding the diversity of food available in households with the incidence of stunting in children, it was found that the more various foods contained in the household, the lower the risk of stunting in children. These results remained significant after adjusting for the number of family members, expenditure on food, mother's education, the presence of family members who breastfeed, energy and protein intake [7].

Protein is essential for the growth of children. Protein serves as a building block for the body's structural components, especially muscles and bones. In addition, protein acts as a transport and storage of nutrients, enzymes, the formation of antibodies, and energy sources. Children need adequate protein intake for muscle and bone growth [14]. Good muscle and bone growth will support muscle and bone mass and strength to support the movement that becomes motor skills [15].

Most of the subjects' energy adequacy level was in the deficit category (59\%). Based on table 6 , it can be seen that children with sufficient energy deficit levels are more likely to be found in parents who practice the neglectful feeding style. In contrast, good energy adequacy is found in parents who practice an authoritative feeding style. In ignoring the feeding style, parents are low in making demands and demands. Parents' neglect makes children feel they do not get love and attention, so they have a terrible diet and lack energy intake. Authoritative feeding style, parents provide demands and responses in a balanced manner. Parents are full of warmth and love. Authoritative feeding style will influence good eating behaviour in children [10]. This is indicated by the child having a good level of energy intake.

Children's eating behaviour is influenced by the way parents interact with their children, which depends on the parenting pattern of their children. Parents who practice an authoritarian feeding style show low control eating patterns. Parents who have an authoritative feeding style show parenting patterns by providing monitoring, modelling and promoting healthy eating as well as providing healthy food for their children at home [16].

Based on Table 7, it can be seen that children with adequate protein deficit levels are more commonly found in parents who practice permissive feeding style, while children with good protein adequacy are more commonly found in parents who practice authoritarian feeding style. Protein intake that is often consumed comes from vegetable ingredients (such as tempeh and tofu). Sources of animal protein consumed are eggs, catfish, chicken meat, sausages, nugget and tempura. Few children consume milk. There are still many children who consume sweetened condensed products because children tend to like the taste. Parents still think that sweetened condensed products are milk.

The feeding style of parents affects children's eating and snacking patterns. Parents who impose food restrictions on children make children happy to consume snacks that tend to be high in calories, have a sweet taste, and are low in nutrients [17]. Parents who apply authoritarian parenting have toddlers with better eating patterns than parents who apply authoritative or permissive parenting [18].

Overprotective parents tend to put pressure on eating and high involvement in the child's diet. While in the authoritarian feeding style, parents provide strict control over the child's eating behaviour, they also apply rules that children must obey to control children's intake. 
The use of food as a reward or as a punishment is also applied in an authoritarian feeding style [16].

Malnutrition in children is related to parenting interactions with children, especially parenting in feeding (feeding style). In this case, the mother plays a significant role in child care, including feeding [19]. Socio-cultural factors play an essential role in influencing the practice of feeding style [20]. In this study, most of the subjects were cared for by their mother (76.9\%), fathered by their father $(3.3 \%)$ and some were cared for by other people $(19.8 \%)$, usually their grandmother. Although more than half of the subject's mothers work (52.7\%) to help the family's economy, there are still mothers who can still take care of their children because they work only part-time, namely in self-employment, labour and farmers. In conditions of child care carried out by others, the responsibility for feeding is also carried out by others.

The factors of feeding style practices that can help the child's growth and development are 1) interactive feeding according to the child's age stage; 2) choosing foods that are in accordance with the child's eating abilities and tastes; 3 ) being responsive to cues of hunger in children; 4) eat in a comfortable atmosphere; 5) talk about good things and play in the context of food. Good responses from parents related to feeding style will help children in eating well [21].

Good feeding style is related to the family's ability to provide time, attention, and support to children to stimulate them to eat well [14]. Attention is obtained from the response element and support obtained from the demand element, and if both are present, the child will get a good food intake. Good food intake is needed as a child's material to grow and develop properly [21].

Feeding style response dimensions are proven to affect children's eating patterns. The response dimension in nurturing food makes hunger signals respond quickly and emotionally supported by the environment, in this case, parents, especially mothers. This rapid response in the short term will benefit the fulfilment of hunger and satiety [22].

In this study, it is seen that the other side of the responsive dimension in the parenting style of eating, parents provide food that children like, which tends to be instant food and easy to prepare. Prepared foods tend to be foods that are low in nutritional value. More than half $(53.1 \%)$ of mothers' status as workers may be related to this condition. Instant foods often provided by mothers are instant noodles, sausages and "kentaki" fried chicken.

Mothers who work socio-economically contribute to the family economy. The availability of food in the family is also more secure. The availability of good food will provide an excellent opportunity for children to get good food intake [23]. However, as a consequence, it will reduce the quantity of time with children. Mothers tend to have feelings of guilt towards their children. On the other hand, there will be feelings of guilt in the mother. As a consequence of this feeling of guilt, mothers tend to reduce cooking and cleaning time to spend time with their children after coming home from work [24]. This reduction in the proportion of time to cook is related to parents choosing to provide food that tends to be easy to prepare.

It was found that children did not eat breakfast for various reasons, including fear of being late, lazy to have breakfast, not having an appetite in the morning and not being used to eating for fear of heartburn and wanting to defecate at school. If the child does not want to eat breakfast, the parents respond by choosing to give pocket money for the child to buy food at school so that the child is not hungry. Snacks available in schools are usually foods that are low in nutritional content. Snack foods often consumed by the subjects are cilok, ciki, wafers, powder drinks and packaged drinks. This snack habit makes children lazy to eat the main food so that their nutritional intake becomes a deficit [14].

Individual nutritional behaviour, in this case, children, is strongly influenced by the environment and settings in the family. Family and home environment children's eating 
behaviour. Factors such as the availability and adequacy of healthy food, involvement of parents and other family members set an example for children. Parental feeding practices can be a strong predictor of children's nutritional status. In order to strengthen the positive role of parents, it can be done by increasing the knowledge and skills of parents and good relations between children and parents so that parents can provide appropriate care for their children [25].

In this study, most of the feeding style interviews $(75.8 \%)$ were conducted on mothers and $(23.7 \%)$ were conducted on fathers, but there were also parents who, when the interviews were conducted, both were present. The working mothers were $52.7 \% \%$, while the fathers were $96.7 \%$ working. For children who have both working parents, someone else who supervises the child is eating is carried out as a caregiver, usually the grandmother. However, the practice of feeding by grandmother to the subject was not carried out. This allows the results of the inconsistency of the statements of parenting styles of eating and parental practices to the subjects. It is necessary to conduct interviews with caregivers so that there is a match between practices and statements in the parenting style questionnaire.

\section{Conclusion}

Parental feeding style correlated with the adequacy of energy and protein levels in children and impacted the incidence of stunting in children aged 6-9 years. One of the efforts to eradicate stunting is to improve children's diet. Parents play an important role in improving the nutritional intake and eating patterns of their children. Education is needed for parents and grandmothers as daily caregivers to apply the right feeding style to their children.

\section{References}

1. W. Y. Abdel Wahed, S. K. Hassan and R. Eldessouki, Malnutrition and its associated factors among rural school children in Fayoum Governorate, Egypt, Journal of Environmental and Public Health (2017)

2. Agency of Health Research and Development, Ministry of Health, Riset Kesehatan Dasar 2013 (Ministry of Health of the Republic of Indonesia, Jakarta, 2013)

3. Direktorat Gizi Masyarakat, Surveilans Gizi (Departemen Kesehatan Republik Indonesia , Jakarta, 2014)

4. P. De, N. Chattopadhyay. Effects of malnutrition on child development: Evidence form a backward distric of India, Elsevier Clinical Epidemiology and Global Healts, 7, 439445 (2019)

5. D.A.P Bundy, N. de Silva, Horton, D. T. Jamison, G. C. Patton (Edt), Disease control priorities child and adolescent health and development, The World Bank, 8 (2017)

6. A. M. Wiiliams, P. S Scuhdev. Assessing and improving childhood nutrition and growth globally, Pediatr. Clin. N. Am. 64, 755-768 (2017)

7. T. Mahmudiono, S. Sunarmi and R. Richard, Household dietary diversity and child stunting in East Java, Indonesia, Asia. Pac. J. Clin. Nutr., 26, 317-325, (2016)

8. F.J. Ninivaggi, Biomental child development perspectives on psychology and parenting, Rowman \& Littlefield Publisher Inc. United Kingdom (2013)

9. D.E. Papalia, R.D. Feldman, Menyelami Perkembangan Manusia, Penerbit Salemba Humanika, Jakarta, (2014) 
10. A.M. Yuniarti, C.I. Pamela, Pola asuh makan oleh ibu bekerja dengan status gizi siswa di SDN Ngrame Kecamatan Pungging Kabupaten Mojokerto, Medica Majapahit, 8, 919, (2016)

11. S.O. Hughes, T.G. Power, J.O. Fisher, S. Meller, T.A Nicklas, Revisiting a neglected construct: parentyng styles in a child-feedibf context, Appetite 44, 83-92, (2005)

12. J. Peters, J. Dollman, J. Petkov, and N. Parletta, Associations between parenting styles and Nutrition Knowledge and 2-5-year-old childrens fruit, vegetable and non-core food consumption, Public Health Nutrition, 16 (11), 1979-1987 (2012)

13. C. Robinson, B. Mandleco, S.F. Olsen, and C.H. Hart, Authoritative, authoritarian, and permissive parenting practices: Development of a new measure, Psychological Reports, 77, 819-830 (1995)

14. Hardinsya, I.D.N Supariasa, Ilmu Gizi Teori dan Aplikasi, Penerbit Buku Kedokteran, (2016)

15. S. Filteau et al. Associations of vitamin D status, bone health and anthropometry, with gross motor development and performance of school-aged Indian children who were born at term with low birth weight, BMJ Open, 6: e009268. (2016)

16. K. Van der Horst, E.F.C. Sledens, Parenting styles, feeding styles and food-related parenting practices in relation to toddlers' eating styles: A cluster-analitic approach. Plos One. May 24 (2017)

17. R.E. Blaine, A. Kachurak, K.K. Davison, R. Klabunde, and J.O. Fisher, Food parenting and child snacking : a systematic review. International Journal of Behavioral Nutrition and Physycal Activity, 14, 146 (2017)

18. Firdaus, M. Muafif, Analisis pola asuh orang tua dengan status gizi anak prasekolah di RT 01 Desa Manunggal Bangkalan Madura. Surabaya, Jurnal Ilmiah Kesehatan, 9, 2, 215-220, (2016)

19. A.C. Moore, S. Akhter and F.E. Aboud, Responsive complementary feeding in rural Bangladesh, Social science \& Medicine, 62, 1917-1930 (2006)

20. D.T. Bhutia, Protein Energy Malnutrition in India : The Plight of Our Under Five Chidren, J. Family. Med. Prim. Care. Jan-Mar; 3 (1): 63-67, (2014)

21. G.H Pelto, Improving Complementary Feeding Practices and Responsive Parenting as Primary Component of Interventions to Prevent Malnutrition in Infacny and Early Childhood. Pediatrics, 106,1300 (2000)

22. M.M. Black and Abouds, Responsive Feeding Is Embedded in a Theoritical Framework of Responsive Parenting, J. Nutr. 141, 490-494, 201 (2011)

23. J.H Rah, et al. Household sanitation and personal hygiene practices are associated with child stunting in rural India: a cross-sectional analysis of surveys, BMJ Open, 5, e005180 (2015)

24. G. Ramey, V. Ramey, The rug race. in D.E Papalia and R.D Feldman, Menyelami Perkembangan Manusia. Penerbit Salemba Humanika, Jakarta, (2014)

25. MA Morowatisharifabad et al. Parenting style, parental feeding practices and children's nutritional status in authoritative parenting style model: A structural equation modeling. Iran. Red. Crescent. Med. J. March; 19 (3), e41401 (2017) 